\title{
Cell cycle and apoptosis: a map for the GS-NSO cell line at the genetic level and the link to environmental stress
}

\author{
Chonlatep Usaku, David Garcia Munzer, Efstratios N Pistikopoulos, Athanasios Mantalaris* \\ From 23rd European Society for Animal Cell Technology (ESACT) Meeting: Better Cells for Better Health \\ Lille, France. 23-26 June 2013
}

\begin{abstract}
Background
Large scale mammalian cell culture systems, especially fed-batch systems, are currently utilised to manufacture monoclonal antibodies (MAbs) in order to meet the continuously growing global demand [1]. Nutrient deprivation and toxic metabolite accumulation commonly encountered in such systems influence the cell cycle and trigger apoptosis, resulting in shorter culture times and a lower final MAb titre. Control of the cell cycle has been previously studied in order to achieve higher titre through apoptosis inhibition by bcl-2 overexpression and cell cycle arrest in $\mathrm{G}_{1} / \mathrm{G}_{0}$ by p21 transfection. However, the above mentioned strategies have not always been successful; no improvement in titre was often observed though bcl-2 over-expression helped prolong the culture viability whereby the majority of cells were arrested at $\mathrm{G}_{1} / \mathrm{G}_{0}$ to avoid apoptosis [2-4]. Thus, a systematic insight of the dynamic relation between metabolic stress, cell cycle and apoptosis is still required. To this end, we aim to establish a novel map of the dynamic interplay between cell cycle and apoptosis at the genetic level, and provide a link with the culture conditions at the metabolic level.
\end{abstract}

\section{Materials and methods}

Batch culture of GS-NS0 producing a cB72.3 MAb was performed. Cell density and viability was quantified using the dye exclusion method. Extracellular glucose, glutamate, lactate and ammonium were quantified using Bioprofile 400 (Nova Biomedical, Waltham, USA). The extracellular antibody was measured using ELISA. DNA

\footnotetext{
* Correspondence: a.mantalaris@imperial.ac.uk Biological Systems Engineering Laboratory, Centre for Process Systems Engineering, Department of Chemical Engineering, Imperial College London,
} London, SW7 2AZ, UK

\section{Results and discussion}

Our results showed a clear link between the environmental factors and gene expression. The batch cultures started with a high fraction of cells in the $G_{1} / G_{0}$ phase, which rapidly left this state in order to join the proliferating population. Soon after, glutamate deprivation occurred at around $50 \mathrm{~h}$ of culture, whereby atf5 upregulation peaked (50\% higher) suggesting that glutamate deprivation is among the first factors that introduce metabolic stress, in agreement with previous results [5]. The upregulation of atf5 triggered the upregulation of bcl-2 (which followed at around $90 \mathrm{~h}$ ). After the batch cultures reached their maximum cell density (which occurred roughly the same time as the glutamate exhaustion), the onset of an increasing early apoptotic cell population was observed - around $10 \%$. Together with the high cell density, casp 8 was upregulated $(100 \%$ increase). Consequently, the expression of casp 3 followed a similar trend with a lag of few hours as its protein, caspase-3, is one of downstream targets of caspase8 and a final executor of the apoptosis pathways [6]. In addition, $\operatorname{trp} 53 \mathrm{bp} 2$ showed a similar trend to casp 3 . These results suggest that apoptosis could initially occur via the death receptor pathway as marked by the casp 8 upregulation, which might be induced by the glutamate exhaustion and/or the cell density peak. However, given that the trp53bp2 upregulation happened later than that of casp 8 suggests that apoptosis in the later stages of culture might also occur through the mitochondrial 
pathway and it could also be triggered by other lethal signals (e.g. high level of lactate accumulation). As soon as the onset of apoptosis occurred, the upregulation of $p 21$ was also observed (300\% increase) and this happened simultaneously with the $b c l-2$ upregulation. Since it was reported that $\mathrm{Bcl}-2$ protein helps facilitate cell cycle arrest at $G_{1} / G_{0}$ phase and an increase in $G_{1} / G_{0}$ cell fraction was observed later in the death phase of culture, this could suggest that the $b c l-2$ upregulation may underlie the $p 21$ upregulation and the cell cycle arrest at $G_{1} / G_{0}$ phase and this could be a mechanism to avoid apoptosis [7].

\section{Conclusions}

These findings set a map of the cell cycle and apoptotic timing and magnitudes of the events from the genetic level and their links to the environmental conditions, which can be used to gain insight of the GS-NSO cultures. By looking at the map, we can systematically analyse cellular responses to the environmental conditions which may have detrimental effect on the culture and utilise the result of the analysis to tackle the culture issues way before the final executors, but at the genetic level. Ultimately, the goal is to utilize mathematical models that will help to establish new strategies in order to achieve a longer cultivation period, high viability and increased MAb titre.

\section{Acknowledgements}

We would like to thank Lonza Biologics (Slough, UK) for kindly providing the cell line and members of Biological Systems Engineering Laboratory (BSEL)

for help with the analytical techniques.

Published: 4 December 2013

\section{References}

1. Elvin JG, Couston RG, van der Walle CF: Therapeutic antibodies: Market considerations, disease targets and bioprocessing. International Journal of Pharmaceutics 2013, 440:83-98.

2. Simpson NH, Singh RP, Emery AN, Al-Rubeai M: BCl-2 over-expression reduces growth rate and prolongs $\mathrm{G} 1$ phase in continuous chemostat cultures of hybridoma cells. Biotechnology and Bioengineering 1999, 64:174-186.

3. Tey BT, Singh RP, Piredda L, Piacentini M, Al-Rubeai M: BCl-2 mediated suppression of apoptosis in myeloma NSO cultures. Journal of Biotechnology 2000, 79:147-159.

4. Watanabe S, Shuttleworth J, Al-Rubeai M: Regulation of cell cycle and productivity in NSO cells by the over-expression of p21CIP1. Biotechnology and Bioengineering 2002, 77:1-7.

5. Browne SM, Al-Rubeai M: Analysis of an artificially selected GS-NSO variant with increased resistance to apoptosis. Biotechnology and Bioengineering 2011, 108:880-892.

6. Hengartner MO: The biochemistry of apoptosis. Nature 2000, 407:770-776.

7. Janumyan YM, Sansam CG, Chattopadhyay A, Cheng N, Soucie EL, Penn LZ, Andrews D, Knudson CM, Yang E: BCl-xL/BCl-2 coordinately regulates apoptosis, cell cycle arrest and cell cycle entry. EMBO J 2003, 22:5459-5470.
doi:10.1186/1753-6561-7-S6-P54

Cite this article as: Usaku et al:: Cell cycle and apoptosis: a map for the GS-NS0 cell line at the genetic level and the link to environmental stress. BMC Proceedings 2013 7(Suppl 6):P54.

\section{Submit your next manuscript to BioMed Central and take full advantage of:}

- Convenient online submission

- Thorough peer review

- No space constraints or color figure charges

- Immediate publication on acceptance

- Inclusion in PubMed, CAS, Scopus and Google Scholar

- Research which is freely available for redistribution

Submit your manuscript at www.biomedcentral.com/submit
C Biomed Central 